IJAEDU- International E-Journal of Advances in Education, Vol. 2, Issue 4, April 2016

\title{
QUALITIES TO BE MET BY THE UNIVERSITY OF BAHRI TEACHING STAFF MEMBER BASED ON THE STUDENTS OF THE FACULTY OF EDUCATION VIEWS
}

\author{
Abubaker Osman Mohammed Jaber \\ Dr., University of Bahri, Sudan, Khartoum, jaber abubaker@yahoo.com
}

\begin{abstract}
The study aims to know the character that should be available in the staff member in University of Bahri to be as a tool for student evaluation for staff member with regard to personal dimension, educational qualifying dimension, and relationship with student, and also know whether there are significant differences among these dimensions with regard to sex, specialization, and academic level of the student. Researcher used analytical descriptive method and determines the tool of the study according to the objectives, questions, and methodology of the study, where the Researcher chooses the questionnaire to collect data from students of the Faculty of education with their different levels. The most important findings of this study were that the member must be in a good character, takes into account Islamic values, encourage students to share their opinions during lecture, have the ability to direct and guide student, and have paternal character. In light of these finding, Researcher presented recommendations it deems important to adopt character contained in the questionnaire as a basis for evaluation of staff member in University of Bahri by student, and adopt traits relating to educational qualifying as a basis for identifying the training needs of staff member in the university
\end{abstract}

Keywords: staff member, student evaluation, personal dimension, educational qualifying dimension.

\section{INTRODUCTION}

There is no doubt that Teaching Career is Great and noble. Before being a career it is a mission like the apostles', Allah Says "It is He Who has sent from amongst unlettered a messenger from among themselves to rehearse to them His signs, to purify them and to instruct them in the Book and Wisdom, although they had been before in manifest error. (Verse (2) Surat Al-Gummuah. The Almighty further says"A similar (favor have ye already received) in that We sent among a messenger of your own, rehearsing to you our signs, and purifying you, and instruct you in scripture and wisdom and in new knowledge" (verse (151) Surat Al Baqarah, Our honorable Prophet Mohammed (PPUH) says "I was created to be a teacher" (Narrated by Ibn Majah under number 229 in Hadith by Abdullah bin Amr).

Any staff member involved in this honorable job must have a feeling of its gloriousness and its great responsibilities. Thus, he must be as much as possible faithful to his job and perform the mission in a best way. Teaching career is especially holy that requires from its members to have sincere affiliation to it; to 
act honestly, faithfully with devotion and continuous effort to spread knowledge and goodness eradicating illiteracy and evil (Diab, 2006, p. 3)

The good staff member is the base of good teaching. The efficient staff member is considered as one of the basic pillars in the university teaching. $\mathrm{He}$ is the core of the emergent communities due to the great role in preparing individuals for the happiness of their communities. In South and East Asian countries it found that the faculty member is the main factor in attracting students from other countries. The quality of teaching offered by the university is directly linked to the teaching staff members and their performance, so the staff member was the focus of a lot of studies and research in higher education.

No doubt the teaching staff member needed by the generations in this era which is witnessing knowledge breakthrough and flow of information, revolution in communication means and knowledge technology, and variety in teaching techniques is the staff member of potentials, qualifications and developed quality capabilities to cope with sophisticated and amazing developments witnessed by the universe in the domain of higher education and scientific research. For, the old tools are no longer capable of meeting the requirements of the era and the needs of generation and new communities. Therefore, the teaching staff member we seeking is the one who is a teacher, a researcher, an educator and effective member in serving his community and the mankind community in general. He must be armed with contemporary culture and believes in heritage principles and values, and be literate with some vital international languages close to knowledge of technology communication, aware of the teaching techniques of his specialization and up to date with knowledge in his field of specialization.

\subsection{Problem Statement}

The performance of the university teaching staff member is associated with a group of academic standards, professional controls and the qualities all are reflected on the level of his professional performance, thus affecting on the outputs of the teaching and the educational process. The studies have confirmed that there is close relationship between the qualities of the individual and work in a certain job. It is found out that the professions require availability of some characters and deeds for those who practice them so that they can achieve the tacks and responsibilities assigned to them in a perfect way. The Researcher considers that the academic efficiency, though it is important in the field of university teaching, it is not the effective factor in this field. There are other factors of great importance which play a big role in determining the extent of the individual' fitness and ability to practice university teaching profession and success therein. Accordingly, the researcher, in his study, tried to review the viewpoints of the faculty of education students to know the characters that must be available in the university teaching staff member at University of Bahri in the personal dimension, the educational qualifying dimension and the dimension of the relation with the students.

\subsection{Importance of the Study}

The importance of this study is an attempt by the Researcher to list characters that suggested by the Faculty of Education Students to be necessary and available in University of Bahri teaching staff members in general and Faculty of Education Teaching Staff in particular, This will help the Academic Affairs Secretariat and Control Management in building a tool to assess the University teaching staff members.

\subsection{Objectives of the study}

This study aims to:

1.3.1 List the qualities that must be provided in the teaching staff member of University of Bahri in the personal dimension, educational qualifying dimension and the dimension of relation with the students based on the students' feedback.

1.3.2 Find out if there were statistically significant differences between the three dimensions of the qualities that must be met in the University of Bahri Teaching Staff Member.

1.3.3 Find out if there were statistically significant differences between the three dimensions of the qualities that must be met in the University of Bahri Teaching Staff Member with regard to gender, specialization, and academic level of the student. 


\subsection{Study questions}

1.4.1 What are the main qualities that are supposed to be met by teaching staff members of the University of Bahri in the personal dimension, educational qualifying dimension and the dimension of relationship with the students as per students' views?

1.4.2 Are there significant differences among the qualities that must be met in the teaching staff member in the personal dimension, educational qualifying dimension and the dimension of relationship with the students?

1.4.3 Are there significant differences between the qualities that must be met in a the teaching staff member in the personal dimension, educational qualifying dimension and the dimension of relationship with the students with regard to the gender variable, specialization and the academic level of the student?

\section{5 limitations of the study}

\subsubsection{Topic Limits}

This study is limited to knowledge of the qualities that must be met in the teaching staff members in the personal dimension, educational qualifying dimension and the dimension of relationship with the students.

\subsubsection{Place Limits}

University of Bahri, Faculty of Education; all specializations and all levels.

\subsubsection{Time limits}

The academic year 2014 - 2015 second semester.

\subsection{Methodology and tools}

The Researcher used the descriptive analytical method which describes the phenomenon in question, and carries out comparison, interpretation and evaluation in the hope of reaching meaningful generalizations that increase the stock of knowledge of the phenomenon in question (Abou Hatab and Sadig, 1991, pp. 102-105). The study tool is represented in a questionnaire to identify the qualities that must be met the teaching staff members in the personal dimension, educational qualifying dimension and the dimension of relationship with the students.

\subsection{Study population and size}

The study population is represented in the students of the University of Bahri Faculty of Education for the academic year 2014 - 2015 second semester totaling to (3020) male and female students divided into different specializations in the faculty.

The study sample was chosen randomly class-based according to their proportional representation $10 \%$, where the sample number attained (302) male and female students.

\section{THEORETICAL FRAMEWORK AND PREVIOUS STUDIES}

\subsection{Theoretical Framework}

\subsubsection{The teaching process foundations in the higher teaching}

2.1.1.1 Teaching Staff Member: must be provided with personal qualities, professional efficiency, educational competence, academic proficiency, communication skills, desire to learn, contribution to community service, as well as improving academic training level for the teaching staff members.

2.1.1.2 University student: this is achieved by taking into account key aspects such as giving attention to students needs in different areas, allowing students to participate in the development of higher teaching, developing counseling and orientation services and guidance, giving attention to university students life and the services supporting that, giving attention to students' problems and management of potentials. 
2.1.1.3 Curricula and Courses: The curricula and courses should be of clear mission and strategic vision for the development of curricula available, be committed to the discipline view in the process of curricula development, adoption of strategic planning methodologies and verification of customer satisfaction.

2.1.1.4 University Administration: the university administration must provide the technical means for the development of university work, the development and the laws of the university work systems, the followup of academic performance of teaching in general, and the methods and activities. These dominant activities should be of high quality, such as availability of classrooms, the library, the laboratories and their equipment, offices for teaching staff members, workshops for practical training, facilities for student services, provision of equipment for the use of modern technology in management, teaching and learning as well as the appropriate health facilities and services.

2.1.1.5 The Surroundings: namely, the teaching institution must consider the needs of the surrounding community by connecting the various specializations in the teaching institution with the community needs. The university must seek to improve the values, traditions and customs prevailing among the people of the community and what makes them attain the required level. The administrative staff of university must be characterized by efficiency and effectiveness. (Fatlawi 0.2008: 55)

\subsubsection{The importance of teaching in Higher Education}

The importance of teaching in higher education lies in several points including:

2.1.2.1 The progress of the community largely depends on the teaching product because it is the most precious and rarest and product in any community.

2.1.2.2 Higher Education having a big share from the State budget makes attention be given to the institutions of the Higher Education to maximize the return from this spending.

2.1.2.3 Huge expansion of Higher Education, which led to the loss of some of the conditions of teaching in higher education, which further led to poor preparation of many graduates for life and work.

2.1.2.4 The responsibility of Higher Education institutions in the preservation of cultural and national identity and in providing students with a type of thinking and knowledge that enables them to adapt and cope with every shift.

2.1.2.5 Increased demand for skilled professionals who know how to accomplish the work of high complexity as well as enabling them to cope with technology.

2.1.2.6 Increased international movement of students with the internationalization of the growth of global markets to attract foreign students from other countries who pay their education expenses.

2.1.2.7 The arrival of large numbers of students to the end of the education with low outcome levels and without enthusiasm for education.

2.1.2.8 The quality role in improving teaching and activation of outputs to meet the needs of the labor market by improving the input and teaching processes. (First Arab Conference for Quality Assurance, 2011.710)

\subsubsection{Higher Teaching and Teaching Staff Members}

The selection and development of qualified teaching staff and retention thereof is among the important issues of the teaching institution. The Teaching staff members are entrusted with the responsibility to implement the teaching programs. Therefore, the teaching institution must have an adequate number of qualified teaching staff members to achieve its mission and objectives, (Sayeh.2010: 12-13). There are qualities associated with the teaching staff member summed up in whole in personal qualities, academic qualification and teaching skills where studies pointed out qualities and characteristics of the teaching staff members as follows:

\subsubsection{Personal Qualities of Teaching Staff Members:}

Studies were conducted on a sample of students and teaching staff members, including the study of Abu 
Humeidan and Soaked in 2008 to find out the most important qualities and characteristics of a good university professor. It was found out that the most important of these qualities are: joviality, fun, attention to the external appearance, timeliness of lectures, good listening, enthusiasm, modesty, respect and pride on his profession, non- smoking in lecture room and commitment to Islamic values. (Abu Humeidan and Soaked, 2008)

\subsubsection{Academic and Educational Qualifying for Teaching Staff Members:}

Some studies such as Hamada study in 1988 have shown that the most important qualities and characteristics that should be manifested by the teaching staff member in this aspect in mastering his academic subject and careful follow-up for researches he finds therein, participation in public forums and lectures, as well as giving attention to writing of academic research, authoring and publishing, the average experience in university teaching after obtaining $\mathrm{PhD}$ and receiving prizes or academic appreciation certificates local or global, his participation in the membership of academic or professional associations locally or globally, average number of theses supervised by him and a number of Arab and foreign academic scientific conferences attended by him (Hamada, 1988). The same studies confirmed that the most important characteristics and qualities associated with the educational aspect is the development of the spirit of thinking and innovation among students, impartiality and fairness in dealing with students, enthusiasm for teaching the material, excellence in the art of teaching through knowledge of different teaching methods, attention for academic orientation and guidance for the student, use of humor, help students outside the lecture room when needed, encourage and respect different points of view of the students, and encourage establishment of friendly cooperating relationships among students, creating a climate of trust by encouraging students to learn from their mistakes (Abu Humeidan and Soaked, 2008, Hamada1988).

\subsubsection{The teaching staff members and the relationship with the students:}

\subsection{Teaching Staff Member an educator and educational mentor:}

In light of the evolution of ongoing educational and psychological science, the role of the teaching staff member is no longer limited to just conveyance of information to students but beyond that to serve as a guide and educational mentor for students through positive interaction process that makes a teaching staff member a model in his general behavior and emotional moderateness so that he can create an educational environment that contributes to the continuity of human relations and the development of cognitive levels to increase the vitality, activity and rush of students towards teaching situations and turn them from the silence and negative state to the state of the debate and academic dialogue, and increase their self-confidence. This in turn leads to the rise of the students' motivation for teaching and learning. The satisfaction of students towards a teaching staff member is among the factors that motivate them to love teaching and the rush to continue to seek knowledge and understand the academic material. This requires from each teaching staff member to introduce himself as an educational and behavioral model at the same time. In this domain, the educational guidance should play its vital role and there should be a Committee for Educational guidance in every faculty and there must be an educational guide in every classroom and be chosen from among those who have experience and efficiency in humanitarian and educational treatment with students. When the teaching staff member be an educational educator and a guide to his students, he can be characterized by the following qualities:. (Maggie, 2012: 1032- 1045)

1. To help students for educational and psychological problems and help them in social adaptation with the university environment.

2. Honesty in word and work with the students.

3. Guide students requiring adherence to and compliance with university regulations.

4. Development of educational ideals and values and ethical behavior in students.

5. To instruct students and educate them to understand themselves and their university environment.

6. To raise the level of ambition of the students and develop their talents. 
7. Take into account the interests of students and tendencies and differences and diversity among them.

\subsection{Teaching Staff Member As An Educational Leader:}

Leadership is the art of influencing human behavior to guide a group of people towards a particular goal. As a teaching staff member is the educational leader in the field of his work in general and in the context of his classroom environment in particular, he should be familiar with and aware of the nature and types of leadership and the personal qualities that he must meet, whether an authoritarian or democratic educational leader. There are a number of types of leadership but the Researcher in this scientific paper will just explain two types of leadership which are, authoritarian leadership (the authoritarian), the Democratic Leadership (Ibrahim, 2003).

\subsection{Authoritarian Leadership (Authoritarian):}

The teaching staff member in his capacity as an educational leader in the field of his work is often severe and authoritarian, who says do that and do not do that in everything. No one of the students is entitled students to argue him in the lecture, because he is often despotic opinionated and imposes on students silence, obedience and execution. He does not allow students to express their opinions and inquire about mysterious academic topics (Sheikh, 2000). The authoritarian teaching staff member under this teaching climate depresses the students' morale and weaken their self-confidence makes them lose psychological safety and satisfaction of and contributes to the decline in the academic level of his students and adversely affects their ambition, confuses the process of teaching and weakens the outputs of teaching. The most prominent characteristics that the authoritarian teaching staff member is featured with are following: (Maggie 2012: 1032-1045).

1. Arrogance and haughtiness towards the students.

2. He does not listen and does not care about the views of the students.

3. He deals harshly with the students.

4. He cares of explaining the subject more of his attention to students.

5. Love of control and domination on the students.

6. He does not accept any criticism of his students.

7. He does not cooperate with the students and does not respect them.

\subsection{Democratic Leadership:}

The teaching staff member as a democratic educational leader in the field of his work moves actively and interacts in the light of the humanitarian and educational values and the interests that he practices, respects the learner humanity and allows him to express his views and discuss with the professor the academic material. The democratic university professor often tends to create positive environment for students in which students' motivation for teaching and learning stand out and be dominated by psychological safety and satisfaction away from fear and anxiety, and adopts moral incentives in teaching such as praise and thanksgiving, leading to lift their spirits and encourage them to excel and to continue to seek knowledge and know-how. This in turn contributes to the improvement of the students' academic level and development of teaching process and lead to quality teaching outputs. (Tai and Kadadah, 2003).

\subsection{Teaching Staff Member as an Academic Researcher:}

Attention to scientific research to achieve the ambitions of communities in development and progress has increased. The communities began to search for scientific methods to create appropriate solutions to their problems. There is also increasing interest towards academic and educational institutions in universities to conduct scientific research to keep pace with progress in various fields of life and community activities (Fatlawi, 2008: 20).

The scientific research is a national treasure of any nation that believes in it, encourage it and support it by all methods and different means. It combines science, experience, art and creativity. It is the best way 
for the development and progress of communities. Our need for scientific research is increasing day by day. The world is in unprecedented race towards the biggest amount of the scientific knowledge which ensures the evolution of man and community and guarantee human superiority in order to provide the conditions and the right opportunities for human survival enjoying the well-being and security and for the progress and development of the community. The teaching staff member must be characterized by the following qualities in this regard. (Hayati. 2005)

1. Availability of desire and the self-motivation and resilience.

2. The tendency to read and see what has been written in the field of scientific competence.

3. Show scientific honesty.

4. The ability to organized thinking in accordance with scientific methodology.

5. Accuracy the ability to innovation and creativity.

6. Communication Skill and language proficiency.

\subsection{Literature Review}

Abu Humeidan and Soaked conducted a study in 2008 entitled the qualities to be met by a teaching staff member according to Mu'tah University students' feedback, where the study aimed to find out the qualities that the University of Mu'tah students suggested to be met by the teaching staff member. The Researcher used the descriptive method, a questionnaire tool and random cluster sample amounting to 700 students from Mu'tah University. The Researcher used the arithmetic means, standard deviations and unilateral variance analysis to determine the impact of the variance of gender, academic level and college in the grades of the students' desires in the availability of qualities. The most important results in the personal dimension were morality, honesty and faithfulness, tolerance and dedication to work, calmness and moderation. However, the educational qualifying dimension is mastering of material, adequate experience in the conveying of information and clarity of the voice. As for the dimension of relationship with students, the most important qualities were: understanding of the teaching staff member to students' problems and their circumstances, objectivity in dealing and non-fanaticism. (Abu Humeidan and Soaked, 2008)

Maggie conducted a study in 2012 entitled Evaluation of Teaching Staff Member in Quality Assurance. The Study aimed to illustrate the importance of evaluating the teaching staff member in terms of specifications, characteristics and functions. The Researcher used the descriptive analytical method by which concluded to results the most important of which is that the evaluation of the teaching staff member constitutes an essential factor in quality assurance, and that the personal and professional specifications and characteristics of the teaching staff member is an important criterion in quality assurance of teaching and assurance of the achievement of the University's mission and goals (Maggie, 2012: 1032-1045).

Hamada study of 1988, which aimed to find out the views of a group of Kuwait University students about the qualities that must be met by a teaching staff member in general, as well as the qualities that they think their professors at the University of Kuwait are characterized with. The Researcher designed a questionnaire included (42) items distributed on four themes and applied to a sample from university students composed of (100) students from different specializations. The results of the study showed that the most important qualities that the teaching staff member should meet are to be able to convey the material and to be of clear explanation, be fair to his students and dedicated to his work. The results also showed that there is a negative view of the sample population towards their professor, where the majority of respondents think that a few of Kuwait University teaching staff members meet the qualities

That they think must be met by the university professor. (Diab, 2006)

\subsubsection{Comments on Literature Review}

Through the previous presentation of Literature Review, it is remarked that these studies dealt with the qualities that must be met in a teaching staff member from the perspective of students or by the quality assurance standards of a teaching staff member. These studies have agreed to use the descriptive approach and survey the views of students or educational literature available in this important area; in the 
teaching process. The current study has agreed with the literature review in the use of the descriptive approach in the study sample. It is characterized by all specializations of the Faculty of Education students' survey as they researchers in the near future. The Researcher believes that Literature Review provided a benefit to the present study through identify the literature that it dealt with as well as the use of the descriptive approach, building of the study tool and method of analyzing the data statistically.

\section{THE PROCEDURES OF FIELD STUDY}

\subsection{Study Approach \& Tool}

The Researcher used the descriptive analytical method which describes the phenomenon in question and carried out comparison, interpretation and evaluation in the hope of reaching meaningful generalizations that increases the stock of knowledge of the phenomenon in question (Abou Hatab and Sadig, 1991, pp. 102-105). The study tool is represented in a questionnaire directed to the students of Faculty of Education of all the specializations and levels at the University of Bahri.

\subsection{Population and a Sample of the Study}

The study population is represented in the students of the Faculty of Education for the academic year 2014 - 2015 totaling to (3020) male and female students according to the statistics of the Faculty Registrar. The Researcher applied the random, class-based sample method for the choice of the study sample from the original population amounting to (291) male and female students. Table No (1) indicates the frequencies and the percentages of the sample population distribution by gender.

Table (1) Frequencies and percentages for members of the sample by gender

\begin{tabular}{|l|c|c|c|}
\hline \multicolumn{1}{|c|}{ Type } & Male & Female & Total \\
\hline Frequency & 136 & 155 & 291 \\
\hline percentage & $46.7 \%$ & $53.3 \%$ & $100 \%$ \\
\hline
\end{tabular}

The Researcher adopted the random, class-based sample selection in totaling 302 students University of Bahri Faculty of Education of all specializations. Table No. (2) Indicates the frequencies and percentages for members of the sample according to specialization.

Table (2) Frequencies and percentages for the distribution of respondents by Specializations at the Faculty of Education

\begin{tabular}{|l|c|c|}
\hline \multicolumn{1}{|c|}{ Specialization Type } & Frequency & percentage \\
\hline Physics - Mathematics & 16 & $5.5 \%$ \\
\hline Arabic - English & 1 & $0.3 \%$ \\
\hline Chemistry - Biology & 7 & $2.4 \%$ \\
\hline Geography - History & 18 & $6.2 \%$ \\
\hline Art Education & 2 & $0.7 \%$ \\
\hline Pre-school education & 5 & $1.7 \%$ \\
\hline Basic Education & 62 & $21.3 \%$ \\
\hline Biology & 16 & $5.5 \%$ \\
\hline Physics & 10 & $3.4 \%$ \\
\hline Chemistry & 14 & $4.8 \%$ \\
\hline Mathematics & 11 & $3.8 \%$ \\
\hline
\end{tabular}


IJAEDU- International E-Journal of Advances in Education, Vol. 2, Issue 4, April 2016

\begin{tabular}{|c|c|c|}
\hline Geography & 27 & $9.3 \%$ \\
\hline History & 22 & $7.6 \%$ \\
\hline Arabic & 40 & $13.7 \%$ \\
\hline English & 40 & $13.7 \%$ \\
\hline Total & 291 & $100 \%$ \\
\hline
\end{tabular}

Table (3) The Frequencies and Percentages of Respondents' Distribution by level at the Faculty of Education

\begin{tabular}{|l|c|c|c|c|c|}
\hline \multicolumn{1}{|c|}{ Level } & First & Second & Third & Fourth & Total \\
\hline Frequency & 131 & 88 & 48 & 24 & 291 \\
\hline percentage & $45 \%$ & $30.2 \%$ & $16.5 \%$ & $8.2 \%$ & $100 \%$ \\
\hline
\end{tabular}

\section{PRESENTATION AND DISCUSSION}

Presentation and discussion of the first question, which reads (What are the main qualities that the students of the Faculty of Education at the University of Bahri consider that they are supposed to be in the teaching staff members in the personal dimension, educational qualifying dimension and the dimension of relationship with the students?).

Table (4) Students Feedbacks on the Teaching Staff in the in the personal dimension

\begin{tabular}{|c|c|c|c|c|c|c|c|}
\hline $\mathbf{s}$ & Statement & Agree & Neutral & Not agree & $\begin{array}{c}\text { Arithmetic } \\
\text { mean }\end{array}$ & $\begin{array}{l}\text { standard } \\
\text { deviation }\end{array}$ & Judgment \\
\hline 1. & $\begin{array}{l}\text { To have good } \\
\text { manners. }\end{array}$ & $\begin{array}{c}285 \\
97.9 \%\end{array}$ & $\begin{array}{c}6 \\
2.1 \%\end{array}$ & $\begin{array}{l}0.00 \\
0.00 \%\end{array}$ & 2.98 & 0.142 & Approval \\
\hline 2. & $\begin{array}{l}\text { Be characterized with } \\
\text { calmness and self- } \\
\text { confidence. }\end{array}$ & $\begin{array}{c}275 \\
94.5 \%\end{array}$ & $\begin{array}{c}15 \\
5.2 \%\end{array}$ & $\begin{array}{c}1 \\
0.3 \%\end{array}$ & 2.94 & 0.249 & Approval \\
\hline 3. & $\begin{array}{l}\text { To have a sense of } \\
\text { humor and fun. }\end{array}$ & $\begin{array}{c}183 \\
62.9 \% \\
\end{array}$ & $\begin{array}{c}97 \\
33.3 \% \\
\end{array}$ & $\begin{array}{c}11 \\
3.8 \% \\
\end{array}$ & 2.59 & 0.564 & Approval \\
\hline 4. & $\begin{array}{l}\text { Be stick to the time of } \\
\text { his lectures. }\end{array}$ & $\begin{array}{c}275 \\
94.5 \% \\
\end{array}$ & $\begin{array}{c}12 \\
4.1 \% \\
\end{array}$ & $\begin{array}{c}4 \\
1.4 \% \\
\end{array}$ & 2.93 & 0.303 & Approval \\
\hline 5. & Be good-looking. & $\begin{array}{c}237 \\
81.4 \%\end{array}$ & $\begin{array}{c}46 \\
15.8 \% \\
\end{array}$ & $\begin{array}{c}8 \\
2.7 \%\end{array}$ & 2.79 & 0.473 & Approval \\
\hline 6. & $\begin{array}{l}\text { Be committed to the } \\
\text { values and customs } \\
\text { of the community. }\end{array}$ & $\begin{array}{c}216 \\
74.2 \%\end{array}$ & $\begin{array}{c}61 \\
21.0 \% \\
\end{array}$ & $\begin{array}{c}14 \\
4.8 \% \\
\end{array}$ & 2.69 & 0556 & Approval \\
\hline 7. & $\begin{array}{l}\text { Be characterized by } \\
\text { extensive culture. }\end{array}$ & $\begin{array}{c}236 \\
81.1 \%\end{array}$ & $\begin{array}{c}48 \\
16.5 \%\end{array}$ & $\begin{array}{c}7 \\
2.4 \%\end{array}$ & 2.79 & 0.65 & Approval \\
\hline 8. & $\begin{array}{l}\text { To keep pace with } \\
\text { community's } \\
\text { problems. }\end{array}$ & $\begin{array}{c}228 \\
78.4 \%\end{array}$ & $\begin{array}{c}51 \\
17.5 \%\end{array}$ & $\begin{array}{c}12 \\
4.1 \%\end{array}$ & 2.74 & 0.524 & Approval \\
\hline 9. & $\begin{array}{l}\text { To take into account } \\
\text { Islamic values. }\end{array}$ & $\begin{array}{c}270 \\
92.8 \% \\
\end{array}$ & $\begin{array}{c}14 \\
4.8 \% \\
\end{array}$ & $\begin{array}{c}7 \\
2.4 \% \\
\end{array}$ & 2.90 & 0.368 & Approval \\
\hline 10. & $\begin{array}{l}\text { Be proud of his } \\
\text { profession. }\end{array}$ & $\begin{array}{c}259 \\
89.0 \% \\
\end{array}$ & $\begin{array}{c}17 \\
5.8 \% \\
\end{array}$ & $\begin{array}{c}15 \\
5.2 \% \\
\end{array}$ & 2.84 & 0.489 & Approval \\
\hline
\end{tabular}

With regard to Table (4) we find that all the statements have been approved, but by detecting the percentages, we find that there are clear differences in the percentages of statement s; between $97.9 \%$ to $62.9 \%$. The statements received a percentage exceeding $90 \%$, respectively, are: "Enjoy good manners97.9\%", "Be characterized with calmness and self-confidence $94.5 \%$ " Be stick to the time of his 
lectures $94.5 \%$ and "Take into account Islamic values 92.8\%". The comment of the Researcher on the results are that the respondents are well aware of the qualities and characteristics that must be available in a person so that he can be a successful teaching staff member or even a successful teacher in the future. The sample also deals and interacts in the Faculty of Education teaching staff think in them to be a good example that could be followed. The attention of the Researcher was drawn by a statement that reads "Have a sense of humor and fun" by $62.9 \%$, the lowest percentage among the statements contained in this theme, and the comment of the Researcher is that the sample believes that the seriousness in the teaching process is among the qualities and characteristics that must be available in the teaching staff member until he finds appreciation and respect by the students, and these results are consistent with what was reached by the Abu Humeidan and Soaked in 2008, as well as what came in the theoretical literature that the teaching profession is prophets and apostles' career and it requires that a teaching staff member must be characterized with these qualities and characteristics.

Table (5) Views of Students on the Teaching Staff Member with Regard Educational Qualifying Dimension

\begin{tabular}{|c|c|c|c|c|c|c|c|}
\hline S & Statement & Agree & Neutral & Not agree & $\begin{array}{c}\text { Arithmetic } \\
\text { mean }\end{array}$ & $\begin{array}{l}\text { Standard } \\
\text { deviation }\end{array}$ & Judgment \\
\hline 1. & $\begin{array}{l}\text { To takes into account } \\
\text { individual differences } \\
\text { among students while } \\
\text { teaching. }\end{array}$ & $\begin{array}{c}246 \\
84.5 \%\end{array}$ & $\begin{array}{c}21 \\
7.2 \%\end{array}$ & $\begin{array}{c}24 \\
8.2 \%\end{array}$ & 2.76 & 0.589 & Approval \\
\hline 2. & $\begin{array}{l}\text { To have sufficient } \\
\text { know-how, of the } \\
\text { syllabus he is } \\
\text { teaching. }\end{array}$ & $\begin{array}{c}267 \\
91.8 \%\end{array}$ & $\begin{array}{c}21 \\
7.2 \%\end{array}$ & $\begin{array}{c}3 \\
1.0 \%\end{array}$ & 2.91 & 0.324 & Approval \\
\hline 3. & $\begin{array}{l}\text { To use various } \\
\text { university teaching } \\
\text { strategies during the } \\
\text { lecture. }\end{array}$ & $\begin{array}{c}241 \\
82.8 \%\end{array}$ & $\begin{array}{c}39 \\
13.4 \%\end{array}$ & $\begin{array}{c}11 \\
3.8 \%\end{array}$ & 2.79 & 0.492 & Approval \\
\hline 4. & $\begin{array}{l}\text { To determine a clear } \\
\text { plan for performing } \\
\text { the syllabus he is } \\
\text { teaching. }\end{array}$ & $\begin{array}{c}262 \\
90.0 \%\end{array}$ & $\begin{array}{c}24 \\
8.2 \%\end{array}$ & $\begin{array}{c}5 \\
1.7 \%\end{array}$ & 2.88 & 0.372 & Approval \\
\hline 5. & $\begin{array}{l}\text { To encourages } \\
\text { students to participate } \\
\text { with feedbacks during } \\
\text { the lecture. }\end{array}$ & $\begin{array}{c}270 \\
92.8 \%\end{array}$ & $\begin{array}{c}20 \\
6.9 \%\end{array}$ & $\begin{array}{c}1 \\
0.3 \%\end{array}$ & 2.92 & 0.278 & Approval \\
\hline 6. & To have a clear voice. & $\begin{array}{c}273 \\
93.8 \%\end{array}$ & $\begin{array}{c}18 \\
6.2 \%\end{array}$ & $\begin{array}{c}0.00 \\
0.00 \%\end{array}$ & 2.94 & 0.241 & Approval \\
\hline 7. & $\begin{array}{l}\text { To connect the former } \\
\text { lecturer with the new } \\
\text { one. }\end{array}$ & $\begin{array}{c}246 \\
84.5 \%\end{array}$ & $\begin{array}{c}38 \\
13.1 \%\end{array}$ & $\begin{array}{c}7 \\
2.4 \%\end{array}$ & 2.82 & 0.442 & Approval \\
\hline 8. & $\begin{array}{l}\text { To have the skill to } \\
\text { build a good } \\
\text { attainment tests. }\end{array}$ & $\begin{array}{c}146 \\
84.5 \%\end{array}$ & $\begin{array}{c}37 \\
12.7 \%\end{array}$ & $\begin{array}{c}8 \\
2.7 \%\end{array}$ & 2.82 & 0.452 & Approval \\
\hline 9. & $\begin{array}{l}\text { To use a variety of } \\
\text { methods to assess } \\
\text { students } \\
\text { performance. }\end{array}$ & $\begin{array}{c}250 \\
85.9 \%\end{array}$ & $\begin{array}{c}35 \\
12.0 \%\end{array}$ & $\begin{array}{c}6 \\
2.1 \%\end{array}$ & 2.84 & 0.421 & Approval \\
\hline 10. & $\begin{array}{l}\text { Be proficient in the } \\
\text { use of educational } \\
\text { technology. }\end{array}$ & $\begin{array}{c}241 \\
82.8 \%\end{array}$ & $\begin{array}{c}42 \\
14.4 \%\end{array}$ & $\begin{array}{c}8 \\
2.7 \%\end{array}$ & 2.80 & 0.464 & Approval \\
\hline
\end{tabular}

By studying carefully table (5) we find that the statement that reads "to have a clear voice" won the highest percentage among the statements contained in this theme where it reached $93.8 \%$ which in the Researcher's view that the respondents are aware of and familiar with the qualities and characteristics that must be met by the teaching staff member in educational qualifying dimension through what they learn in the educational syllabus that show the faculty requirements. The statement that won second rank 
is "to encourage students to participate with their feedbacks during the lecture by $92.8 \%$. The Researcher agrees with the sample view because among the conditions for improving the lecture strategy is to provide an opportunity for students to participate in the lecture and break the routine so that teaching process should not be teacher-centered but be successful lecture strategy and leads to the desired purpose. The statement which won the third rank at a rate of $91.8 \%$ is the statement that reads "Has sufficient know-how, of the syllabus he is teaching". This result confirms that the teaching staff member must be able to teach the syllabus which also confirms the former view of the Researcher that the sample is fully aware of the teaching profession requirements. The statement that reads "Determines a clear plan for performing the syllabus he is teaching won the fourth rank at a rate of $90.0 \%$. The Researcher's opinion is that planning is the basis of all successful works and that education process does not tolerate randomness and therefore a clear plan for the performance of the syllabus shows students a road map to success and excellence for the said syllabus. The Researcher points out that the statement reads "He must use variety of university teaching strategy during lecture" and the statement "To use educational technology received the lowest percentage $82.8 \%$. In general the Researcher says that these findings are consistent with the findings of concluded by Diab, 2006, Abu Humeidan and Soaked, 2008.

Table (6) Views of Students on the Teaching Staff Member with Regard to the Dimension of Relationship with Students

\begin{tabular}{|c|c|c|c|c|c|c|c|}
\hline $\mathbf{s}$ & Statement & Agree & Neutral & Not agree & $\begin{array}{c}\text { Arithmetic } \\
\text { mean }\end{array}$ & $\begin{array}{l}\text { Standard } \\
\text { deviation }\end{array}$ & Judgment \\
\hline 1. & $\begin{array}{l}\text { To understand the } \\
\text { social conditions of } \\
\text { the students. }\end{array}$ & $\begin{array}{c}244 \\
83.8 \%\end{array}$ & $\begin{array}{c}35 \\
12.0 \%\end{array}$ & $\begin{array}{c}12 \\
4.1 \%\end{array}$ & 2.80 & 0.495 & Approval \\
\hline 2. & $\begin{array}{l}\text { To show flexibility in } \\
\text { dealing with students. }\end{array}$ & $\begin{array}{c}210 \\
72.2 \%\end{array}$ & $\begin{array}{c}65 \\
22.3 \%\end{array}$ & $\begin{array}{c}16 \\
5.5 \%\end{array}$ & 2.67 & 0.577 & Approval \\
\hline 3. & $\begin{array}{l}\text { To humble himself } \\
\text { with students. }\end{array}$ & $\begin{array}{c}236 \\
81.1 \%\end{array}$ & $\begin{array}{c}49 \\
16.8 \%\end{array}$ & $\begin{array}{c}6 \\
2.1 \% \\
\end{array}$ & 2.79 & 0.456 & Approval \\
\hline 4. & $\begin{array}{l}\text { Be objective in } \\
\text { correcting students } \\
\text { workbooks }\end{array}$ & $\begin{array}{c}232 \\
79.7 \%\end{array}$ & $\begin{array}{c}52 \\
17.9 \%\end{array}$ & $\begin{array}{c}7 \\
2.4 \%\end{array}$ & 2.77 & 0.474 & Approval \\
\hline 5. & $\begin{array}{l}\text { Be interested in the } \\
\text { attendance of } \\
\text { students for lectures. }\end{array}$ & $\begin{array}{c}235 \\
80.8 \%\end{array}$ & $\begin{array}{c}46 \\
15.8 \%\end{array}$ & $\begin{array}{c}10 \\
3.4 \%\end{array}$ & 2.77 & 0.495 & Approval \\
\hline 6. & $\begin{array}{l}\text { To have the ability to } \\
\text { instruct and guide } \\
\text { students. }\end{array}$ & $\begin{array}{c}273 \\
93.8 \%\end{array}$ & $\begin{array}{c}12 \\
4.1 \%\end{array}$ & $\begin{array}{c}6 \\
2.1 \%\end{array}$ & 2.92 & 0.343 & Approval \\
\hline 7. & $\begin{array}{l}\text { To be characterized } \\
\text { by paternal spirit. }\end{array}$ & $\begin{array}{c}251 \\
86.3 \% \\
\end{array}$ & $\begin{array}{c}32 \\
11.0 \% \\
\end{array}$ & $\begin{array}{c}8 \\
2.7 \% \\
\end{array}$ & 2.84 & 0.440 & Approval \\
\hline 8. & $\begin{array}{l}\text { Not to threaten } \\
\text { students by the } \\
\text { results of the } \\
\text { examinations. }\end{array}$ & $\begin{array}{c}222 \\
76.3 \%\end{array}$ & $\begin{array}{c}40 \\
13.7 \%\end{array}$ & $\begin{array}{c}29 \\
10.0 \%\end{array}$ & 2.66 & 0.651 & Approval \\
\hline 9. & $\begin{array}{l}\text { To determine office } \\
\text { hours to meet with } \\
\text { students. }\end{array}$ & $\begin{array}{c}183 \\
62.9 \%\end{array}$ & $\begin{array}{c}70 \\
24.1 \%\end{array}$ & $\begin{array}{c}38 \\
13.1 \%\end{array}$ & 2.50 & 0.716 & Approval \\
\hline 10. & $\begin{array}{l}\text { To create a bridge of } \\
\text { communication } \\
\text { outside the lecture } \\
\text { hall. }\end{array}$ & $\begin{array}{c}195 \\
67.0 \%\end{array}$ & $\begin{array}{c}61 \\
21.0 \%\end{array}$ & $\begin{array}{c}35 \\
12.0 \%\end{array}$ & 2.55 & 0.700 & Approval \\
\hline
\end{tabular}

It is noted that the statements of this theme their percentages less than of the two previous themes. The Researcher points out that the highest percentage is $93.8 \%$ won by a statement that reads "To have the ability to instruct and guide students: In the view of the Researcher that the sample opinion is right because this stage is truly in need of counseling and guidance as it requires self-reliance and the stage of completion of the personality formation as well as the student finds himself among intellectual, social and academic freedoms. For this reason he is truly in need of guidance and counseling. The e statement that came in second rank is the one which states that "To be characterized by paternal spirit.", with 
percentage of $86.3 \%$ and this result confirms the former view of the Researcher and its content because the guidance and counseling needs from the teaching staff member to practice the parental role with the student until this process bears fruits and be picked by the student. As for the statement which won the third rank by $83.8 \%$ is that "to understand the social conditions of the students". This result indicates the extent of consistency of the results with each other because each result leads to the next. Counseling and guidance needs the teaching staff member to be of paternal spirit, and this spirit, of course, makes the teaching staff member understand the student's circumstances and treat him as his own son. Allah says"

"It was by that mercy of Allah that you (Prophet Muhammad) dealt so leniently with them. Had you been harsh and hardhearted, they would have surely deserted you. Therefore, pardon them and ask forgiveness for them. Take counsel with them in the matter and when you are resolved, put your trust in Allah. Allah loves those who trust. 》 verse (159) Surat AL-IMRAN

The Almighty also says "Invite to the way of your Lord with wisdom and good instruction, and argue with them in a way that is best. Indeed, your Lord is most knowing of who has strayed from His way, and He is most knowing of who is [rightly] guided" Verse (125) Surat Al-Nahl,

The Researcher feels that the sample is honest in all that it stated. Therefore, in the view of the Researcher it is worthy of appreciation and respect and that it is aware of and understand its obligations and rights and that it will apply all the educational syllabuses it learns in the field of its work in the future. The Researcher points out that these findings are consistent with the findings of Abu Humeidan and Soaked, 2008 which stated the necessity of that the teaching staff member must understand the students' problems and circumstances and objectivity in treatment and being far from fanaticism.

Presentation of the Second Question Discussion which reads ( Are there significant statistical differences between the qualities that must be met in a teaching staff member in the personal dimension, educational qualifying dimension and the dimension of relationship with the students? )

Table (7) Statistical Differences between the Personal Dimension, educational qualifying Dimension and the Dimension of Relationship with the Students

\begin{tabular}{|l|c|c|c|c|c|}
\hline \multicolumn{1}{|c|}{ Variable } & $\begin{array}{c}\text { Number of } \\
\text { sample }\end{array}$ & $\begin{array}{c}\text { Degree of } \\
\text { Freedom }\end{array}$ & Arithmetic mean & $\begin{array}{c}\text { Level of } \\
\text { significance }\end{array}$ & Conclusion \\
\hline $\begin{array}{l}\text { Personal } \\
\text { Dimension }\end{array}$ & 291 & 290 & 2.71 & 0.000 & $\begin{array}{c}\text { Statistically } \\
\text { significant }\end{array}$ \\
\hline $\begin{array}{l}\text { Educational } \\
\text { Qualifying } \\
\text { Dimension }\end{array}$ & 291 & 290 & 2.85 & 0.000 & $\begin{array}{c}\text { Statistically } \\
\text { significant }\end{array}$ \\
\hline $\begin{array}{l}\text { Dimension of } \\
\text { Relationship } \\
\text { with Students }\end{array}$ & 291 & 290 & 2.71 & 0.000 & $\begin{array}{c}\text { Statistically } \\
\text { significant }\end{array}$ \\
\hline
\end{tabular}

It is clear from the Table No. (7) That the significance value of the three dimensions is 0.000 which is less than 0.05 , and this shows that the significance value is high with confidence degree of $95 \%$. It is also evident, through the arithmetic mean of the scores of the sample in the three-dimensions that there are no statistically significant differences between personal dimension differences and the dimension of the relationship with the student where each of the two dimensions got the same arithmetic mean which is 2.71. It is also clear that there is a difference between these two dimensions and the educational qualifying dimension for the favor of the educational qualifying dimension, where its arithmetic mean was 2.85 and this indicates that the study sample, which consists of students from the Faculty of Education at the University of Bahri is having a degree of awareness and understanding of the importance of educational qualifying so that they placed the educational qualifying at the top of the qualities that must be met by the teaching staff member for his importance to the quality of university teaching and learning. The Researcher mentions that this result differs from what had been reached by Abu Humeidan and Soaked, 2008 that there are no statistically significant differences between the three dimensions. 
Presentation of the discussion of the third question which reads (Are there significant differences between the qualities that must be met in the teaching staff member with regard personal dimension, educational qualifying dimension and the dimension of the relationship with the students with regard to the variable gender, specialization and the level of academic student?)

Table (8) Statistical Differences between the three dimensions with regard to Gender Variable, specializations and Student's Level

\begin{tabular}{|l|c|c|c|c|c|}
\hline Variable & $\begin{array}{c}\text { Number of } \\
\text { sample }\end{array}$ & $\begin{array}{c}\text { Degree of } \\
\text { freedom }\end{array}$ & Arithmetic mean & $\begin{array}{c}\text { The level of } \\
\text { significance }\end{array}$ & Conclusion \\
\hline Gender & 291 & 290 & 2.59 & 0.001 & $\begin{array}{c}\text { Statistically } \\
\text { significant }\end{array}$ \\
\hline Specialization & 291 & 290 & 2.67 & 0.000 & $\begin{array}{c}\text { Statistically } \\
\text { significant }\end{array}$ \\
\hline Level & 291 & 290 & 2.93 & 0.000 & $\begin{array}{c}\text { Statistically } \\
\text { significant }\end{array}$ \\
\hline
\end{tabular}

It is noticed from the table (8), that there are significant differences between the arithmetic means for these variables. It is also noticed that there is variation between the differences; the arithmetic mean for the variable of gender is 2.59 and the arithmetic mean for the variable of specialization is 2.67 . It is similarly noticed that there is a difference between these arithmetic means but not a big difference, while it is noticed that the arithmetic mean of the level variable is relatively big compared with the two other variables where the arithmetic mean of the level variable is 2.93. The Researcher attributes this difference to the fact that the grading of the university student between the different levels at the Faculty increases his experience, culture and knowledge of the requirements of the educational process in general and the attributes of a teaching staff member in particular, Since the study sample is of students from the Faculty of Education, the requirements of their university study is Knowledge of the attributes of a good teacher and whatever related to teaching and learning process. This becomes more evident whenever the student progresses in the academic level and this is shown by the result of this comparison. The Researcher suggests that the conclusion reached by him is different from what was reached by Abu Humeidan and Soaked, 2008 that there are no statistically significant differences between the three dimensions with regard to gender of the student or specialization or student level.

\section{THE MOST IMPORTANT RESULTS}

The teaching staff member is to be:

5.1. Enjoy Good manners.

5.2. Characterized by Calmness and self-confidence.

5.3. Committed to the time of his Lectures.

5.4. Take into account Islamic values.

5.5. Clear voice.

5.6. Encourage students to share their opinions during lecture. have the ability to direct and guide student, and have paternal character.

5.7. To encourage Faculty member Students to participate during the lecture.

5.8. Have the ability to direct and guide students.

5.9. Characterized by a paternal character.

5.10. Understand the social conditions of students.

5.11. There are no statistically significant differences between personal dimension and the dimension of relationship with the student. 
5.12. There are significant differences between the three dimensions for the favor of the educational qualifying.

5.13. There are statistically significant differences between the three dimensions with regard to the variable of gender, specialization or level of student, for the favor of the student level.

\section{RECOMMENDATIONS}

6.1. Adoption of the qualities contained in the questionnaire a basis to assess teaching staff y members at the University of Bahri by the students.

6.2. Adoption of the qualities related to educational qualifying as a basis of determining the training needs of the teaching staff members of the University of Bahri.

6.3. Calling on the teaching staff members to familiarize themselves with the qualities that should be met to improve teaching performance in general.

\section{FUTURE STUDIES}

7.1. To conduct a further study to get views from the students of the other faculties at the University on the qualities to be met by teaching staff members.

7.2. To conduct a study to find out the training needs of the teaching staff members at the University of Bahri.

\section{REFERENCES}

- The Holy Quran

- Ibn Majah, Mohammed Bin Yazid, Sunan Ibn Majah, Hadith Number (229) died in year (273) H.

- Ibrahim, Mohammed (2003), System of Teaching Staff Member Formation in the light of the Total Quality Standards, Dar Al Fikr Al Arai for printing and publishing, Amman .

- Abu Humeidan, Yousuf, Soaked land Sari (2008), The Qualities to be met by a Teaching Staff Member as per Mu'tah University students views, Damascus University Journal, Volume 24, 1 st edition.

- Hayati, Siddig (2005), The Role of Higher Education in the Development of Scientific Research, a Workshop on Graduate Education issues, University Sudan.

- Fatlawi, Suhaila Mohsen Kazem (2008), Quality of Teaching, concepts, standards, specifications , responsibilities, 1st edition; Dar Al Shurouk for Publishing and Distribution, Amman .

- Tai, Raad and Gdada, Issa, (2003), Total Quality Management: The concept and the Application Framework in universities and colleges of Administrative Sciences to develop and improve performance levels, Researches of Zarqa Private University, Jordan.

- Sheikh, Mahmoud Badawi (2000), Total Quality of in Islamic Work, Arab Dar Al Fikr Al-Arabi for printing and publishing, 1st edition, Amman .

- Sayeh, Mustafa Mohammed (2010) Quality - quality of teaching - total quality management, vision on the concept and importance, quality world magazine, 1st edition, the first year.

- Sadigg, Aamal and Abu Hatab, Fouad (1991), Research Methodology and methods of statistical analysis in the educational and social sciences, Cairo, Egyptian Anglo library .

- First International Arab Conference of university teaching quality assurance (2011) "The quality of university teaching concept, importance, evaluation methods and standards," Yasser Memon Abbas, Zarqa, University.

- 2nd International Arab Conference for university teaching quality assurance (201 2), The impact of teaching staff member evaluation in the quality assurance, Maggie, Gamar Mohammed Bakhit, Zarqa University. 